Web Site: https://jutq.utq.edu.iq/index.php/main Email: journal@jutq.utq.edu.iq

معادلة حســاب المساحـات الدائرية اللانهــائية

$$
\text { جلي حميد ياسر }
$$

البريد الالكتروني: alihameed_48@yahoo.com

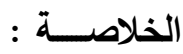

هنالك العديد من الصعوبات والتعقيدات الزائدة عند استخدام المعادلات التقليدية في حساب مساحة او محيط اي شكل دائري. لانه من غير المكن ذللك إلاً بمعرفة بعض العواملكقياس مقطع معين من الدائرة ( القرص) طول المنحني او نصف القطر، يتم عادة تطبيق عدة معادلات لحساب مساحة او محيط شكل دائري(قرص)، ولكن هذه المعادلات التقليدية محدودة جدا لانها تعمل ضمن مجال محدود جدا ايضا، لان عوامل او متغيرات تلك المعادلات يجب ان تكون معلومة، ولكن في بعض الاحيان لربما تكون هذه العوامل غير معلومة وبالتاليسيكون الشكل الدائري مجهول المساحة او مجهول المحيط ، لذلك فانه لامر عظيم ايجاد معادلة جديدة لحساب مساحات او اقطار او محيطات الاشكال الدائرية المجهولة من خلال معرفة ( ثابت ديناميكي او معامل معين)، لذلك فانثابت الكساء الذي اكتثفه الباحث والذي هو قيمة معلومة تمثل كل المجال الذي من المكن لاي مساحة دائرية ان تشغله في كل الفراغ اللانهائي المتاح. وباستخدام المعادلة الجديدة في حساب قطر الدائرة

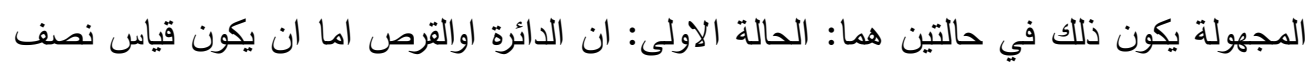

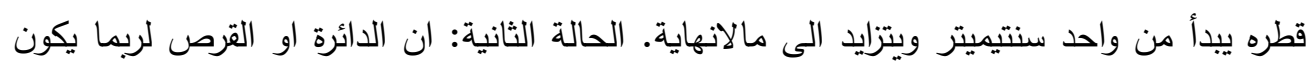

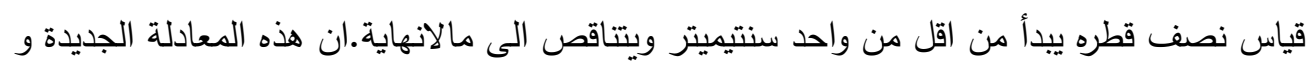
من خلال معاملها (ثابت الكساء) سوف يتيح لاي احد حساب اي مساحة دائرية مجهولة وبصورة مباشرة ودقيقة وسريعة، في مختلف المجالات العلمية كالرياضيات والفيزياء والطب او الفضاء لذلك قدم الباحث هذه المعادلة الجديدة لتعزيز مجالات التكنولوجيا الصناعية، وزيادة التوقع الدقيق في الحسابات من خلال بناء اجزة مبرمجة لحساب المساحات او اية متعلقات اخرى، من المكن ان 
Web Site: https://jutq.utq.edu.iq/index.php/main Email: journal@jutq.utq.edu.iq

$$
\begin{aligned}
& \text { تساعد هذه المعادلات علماء الفضاء لحساب اقطار الاجرام السماوية المجهولة او تعطي تتبوءات } \\
& \text { دقيقة حول توسع الكون. } \\
& \text { كلمات مفتاحية: } \\
& \text { الدائرة، المساحة، الدحيط، المساحة الدائرية، قيمة الكساء، ثابت الكساء. }
\end{aligned}
$$

\title{
INFINITE DISK AREA CALCULATION EQUATION AND KISAA CONSTANT
}

\author{
https://doi.org/10.32792/utq/utj/vol11/3/2
}

\author{
Ali Hameed Yassir \\ Sumer University \\ Email: alihameed_48@yahoo.com
}

\begin{abstract}
There are many difficulties and high complexity today of using traditional equations to calculate the area or circumference of any circular shape, because it cannot be only done by knowing only specific part of circle (disk) curve length (arc) or its diameter (some parameters), Many equations might be apply to compute the circular shapes (area, circumference), but these equations are so limited because these equations work through specific, limited domain, its variables (parameters) must be detected, well known and sometimes cannot be existed. It is a great thing to find new equation to compute any unknown circular area (disk) by using only one knowing (dynamic constant or one parameter). Kisaa constant (the knowing value) that I discovered, represents the hole domain that can any circle (disk) area occupies it in all available space, Using of this equation in the computation of circle diameter is in two cases: First, Circle (disk) that its radius begins from one centimeter and increases to infinite, Second, Circle (disk) that its radius begins from less than one centimeter and decreases to infinite. This new equation by its parameter Kissa constant enables anyone to compute
\end{abstract}


directly, accurately and quickly any unknown circle (disk) area in different scientifically or researching fields like mathematics, physics, medicine or astronomy. Author suggests these two new equations to assist an industrial technologies and to increase the precision in the calculations through building and programming devices to calculate area and other belongings. These equations also help scientists in all fields such as space science to calculate the diameters of celestial bodies and give more accruing predictions of the vacuum and expansion of the universe.

\section{Keywords}

Circle, Area, Circumference, Circular Area, Kissa Value, Kisaa Constant

\section{Introduction}

Ancient and modern ways to calculate area of region enclosed by circle need to know some variables like the radius length or also the circumference of that circle (disk) like Archimedes, Tangent lines, Chord, Sagitta and so on [1]. These ways or equations can be used to calculate the area if there are some or full clear information without make an effortto predict the measurements, as example assume there is a circle (disk) anybody want to compute its area, this means you can use any scalar tools like ruler to calculate its radius then to use the popular equation[2], [3] and [4].Area of circle $=\pi r^{2}$. Area of Circle Equation has many features:

- Area of circle can be computed simply manually [5].

- Many tools are very limited to cover all measurements; because of loosening some basic parts during the measurements (Radius, ruler...) cannot compute an area [6].

- There are not accurate prediction ways or equations to compute an area for the more and more (larger(st)/smaller (st)) surface area that is impossible to imagine its ends[7].

\section{KISAA CONSTANT}

Kisaa constant is computed by using simple geometrical derivation, By Pythagorean theory to find the hypotenuse length of the right angle tool then to find the difference of Tension ofhypotenuse length with the circle (disk) arc. In the next sections the length from point $\mathrm{P}$ to point $\mathrm{Q}$ represents the 
Web Site: https://jutq.utq.edu.iq/index.php/main Email: journal@jutq.utq.edu.iq

Kisaa value if and only radius length is equal to one centimeter. Figure (1) represents any disk circle shape. [8], [9].

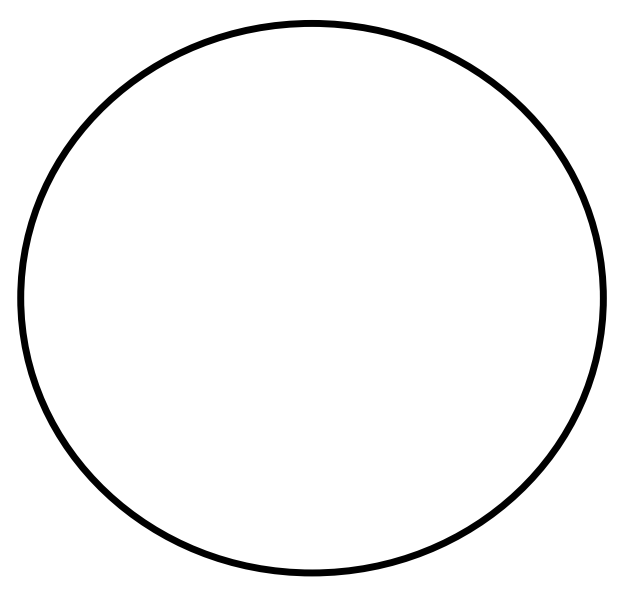

Figure (1)the Circle Shape

Figure (2) represents the structure that author adopted it to initiate the right angle tool.

$Z$ diagonal from infinite to infinite length,

Kessa valve is the mid point when circle

Hypotenuse of the right angle X Y H

$\mathrm{X}$ diagonal $=1 \mathrm{~cm}$

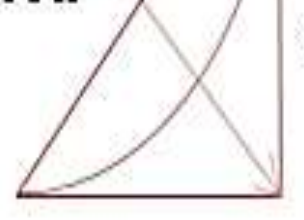

$Y$ diagonal $=1 \mathrm{~cm}$

Figure (2) Right Angle Tool Structure 
University of Thi-Qar Journal Vol.11 No.3 SEP 2016

Web Site: https://jutq.utq.edu.iq/index.php/main Email: journal@jutq.utq.edu.iq 
Web Site: https://jutq.utq.edu.iq/index.php/main Email: journal@jutq.utq.edu.iq

Figure (3) represents the right triangle tool that using to touch any disk by any two points of its circumference.

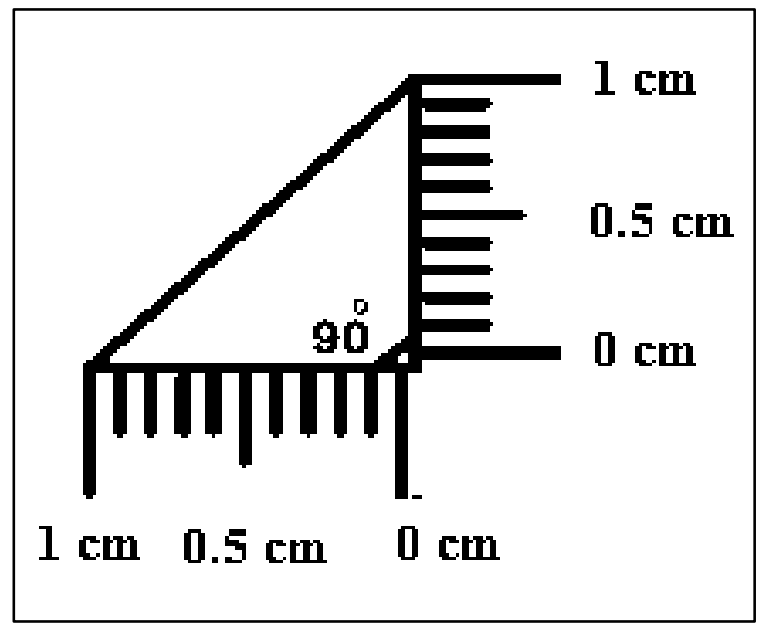

Figure (3) Right Triangle Tool

The right triangle tool has two cases to touch disk's circumference:

A. If the disk touches the right angle by only two points of its ends of one centimeter length (A and D), see figure (4).

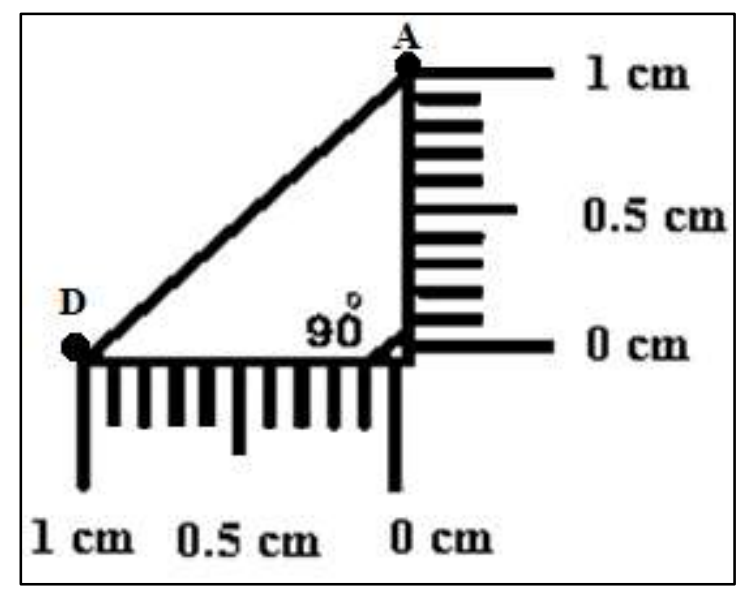

Figure (4) Right Triangle Case 1 
Web Site: https://jutq.utq.edu.iq/index.php/main Email: journal@jutq.utq.edu.iq

B. If the disk does not touch the right triangle by its ends but inside less than one centimeter of its ends, see figure (5).

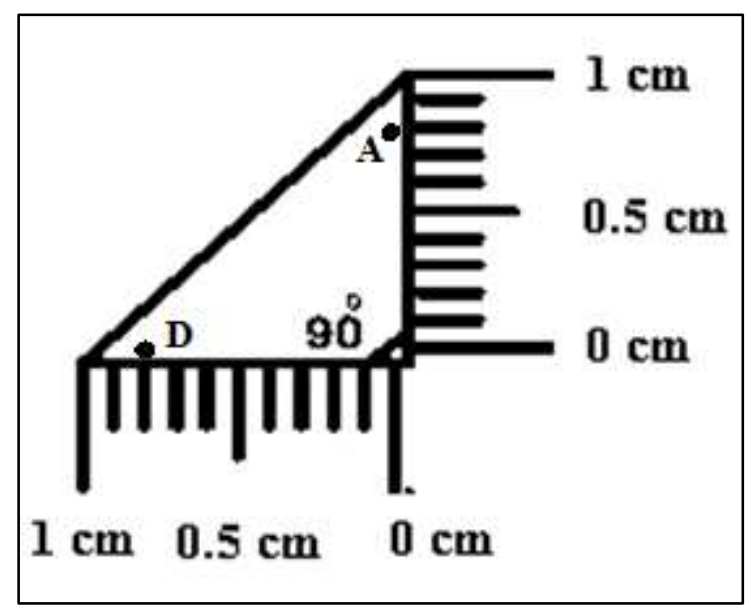

Figure (5) Right Triangle Case 2

For both cases (A and B) there is specialist measurement but in fact the same calculation way is followed in the geometrical derivation.

\section{CASE A GEOMETRICAL DERIVATION}

1. Assume there is a disk has two centimeter diameters (Radius $=1 \mathrm{~cm}$ ) touches the right angle ABD by only A and D points, see figure (6)

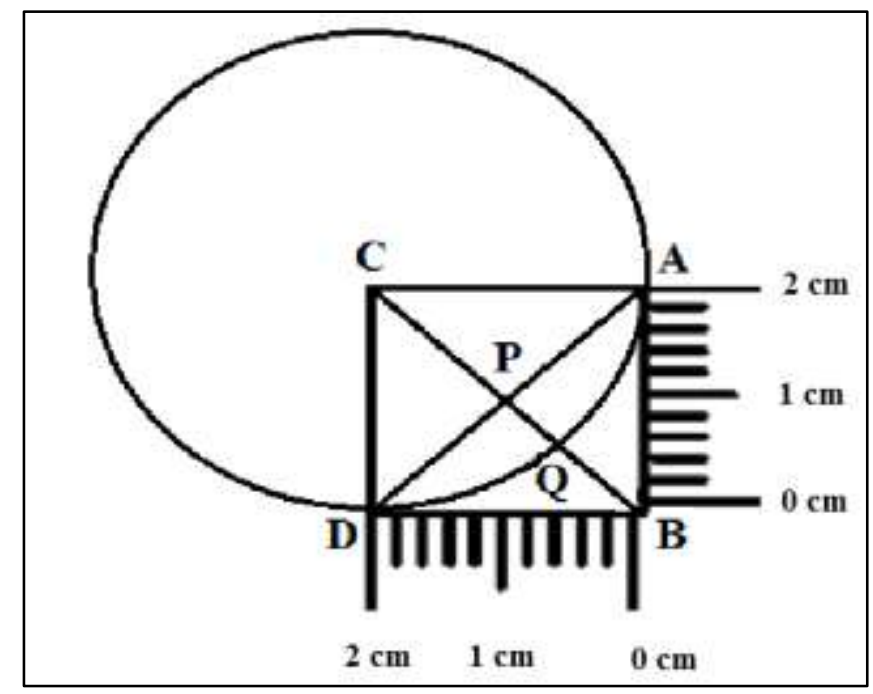


Web Site: https://jutq.utq.edu.iq/index.php/main Email: journal@jutq.utq.edu.iq

Figure (6) Radius Equal to Two Centimeter

From figure (6) disk center is Point $\mathrm{C}$, Right triangle (ABD), Radius $\{\mathrm{CA}$, $\mathrm{CQ}, \mathrm{CD}=1 \mathrm{~cm}\}, \mathrm{AB}=1 \mathrm{~cm}, \mathrm{BD}=1 \mathrm{~cm}$, Square $\mathrm{ABDC}$, Right angle $\mathrm{ABD}=90^{\circ}, \mathrm{AD}$ and $\mathrm{CB}$ are two equal and intersection diagonals of the square $\mathrm{ABDC}, \mathrm{P}$ is the intersection point of the two square's diagonals $\mathrm{AD}$ and $\mathrm{CB}$.

To find PQ:

By Pythagorean.

$$
\mathrm{AB}^{2}+\mathrm{BD}^{2}=\mathrm{AD}^{2}
$$

$\mathrm{AD}^{2}=2$

$\sqrt{\mathrm{AD}^{2}}=1.4142135623730950488016887242097$

$\mathrm{AD}=1.4142135623730950488016887242097$

$\mathrm{AP}=\mathrm{CP}=0.70710678118654752440084436210485$

$\mathrm{PQ}=\mathrm{CQ}-\mathrm{CP}$

$\mathrm{PQ}=1-0.70710678118654752440084436210485$

$P Q=0.29289321881345247559915563789515$

2. Assume there is a disk has Four centimeter diameter (Radius $=2 \mathrm{~cm}$ ) touches the right angle ABD by only A and D points, see figure (7). 
Web Site: https://jutq.utq.edu.iq/index.php/main Email: journal@jutq.utq.edu.iq

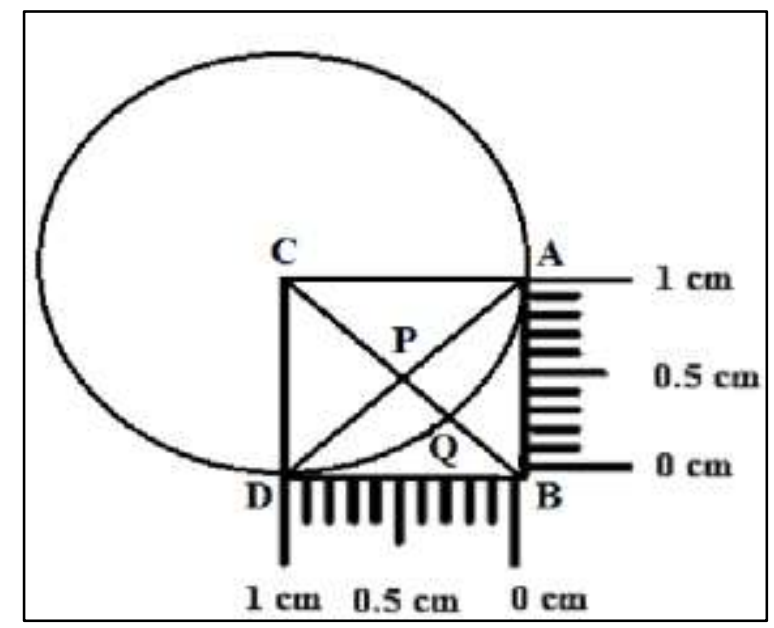

Figure (7) Radius Equal to one Centimeter

From figure (7): Disk center is Point C, Right triangle (ABD), Radius \{CA, $\mathrm{CQ}, \mathrm{CD}=2 \mathrm{~cm}\}, \mathrm{AB}=2 \mathrm{~cm}, \mathrm{BD}=2 \mathrm{~cm}$, Square ABDC, Right angle ABD $=90^{\circ}, \mathrm{AD}$ and $\mathrm{CB}$ are two equal and intersection diagonals of the square $\mathrm{ABDC}, \mathrm{P}$ is the intersection point of the two square's diagonals $\mathrm{AD}$ and $\mathrm{CB}$.

To Find PQ length, by following the same previous steps of the disk that has one centimeter radius results in finding PQ length.

$P Q=0.5857864376269049511983112757903$

3. Same thing happen with the disk of Radius 3 centimeter, $\mathrm{PQ}=0.87867965644035742679746691368545$

And so on, see table (1).

Table (1) Experimental of Increasing PQ length

\begin{tabular}{|c|c|c|}
\hline No. & Disk Radius & PQ length PQ (n) \\
\hline 1. & $1 \mathrm{~cm}$ & $0.29289321881345247559915563789515 \mathrm{~cm}$ \\
\hline 2. & $2 \mathrm{~cm}$ & $0.5857864376269049511983112757903 \mathrm{~cm}$ \\
\hline 3. & $3 \mathrm{~cm}$ & $0.87867965644035742679746691368545 \mathrm{~cm}$ \\
\hline 4. & $4 \mathrm{~cm}$ & $1.1715728752538099023966225515806 \mathrm{~cm}$ \\
\hline
\end{tabular}




\section{CASE A CONCLUSION}

From Table (1) we can conclude there is a constant increasing of PQ length, this increasing or is a constant coefficient equally at each order to the radius increasing, this doubling means there is not ambiguity if the two right angle side be static and remain one centimeter length, Nevertheless the disk can change and have any radius length (increasing more than or equal to one centimeter length), see table (2) applying dividing operation on PQ length values.

Table (2) Ratio Increasing

\begin{tabular}{|c|}
\hline Ratio Increasing \\
\hline$\frac{\mathrm{PQ}(2)}{\mathrm{PQ}(1)}=2$ \\
\hline$\frac{\mathrm{PQ}(3)}{\mathrm{PQ}(1)}=3$ \\
\hline$\frac{\mathrm{PQ}(4)}{\mathrm{PQ}(1)}=4$ \\
\hline So on \\
\hline
\end{tabular}

Fortunately there is a clear ratio can be deduce and it can be used to calculate the radius length. Increasing the length of the disk means the PQ value length will be decreasing in the reversing case with table one (Inverse proportion). This derivation leads us to create a basic formula to calculate any unknowing radius for any disk only by using the right triangle (one by one centimeter) with a dynamic hypotenuse to compute the hypotenuse 
(curving) offset from the original site, Curvature of the hypotenuse toward the right angle, see figure (8).

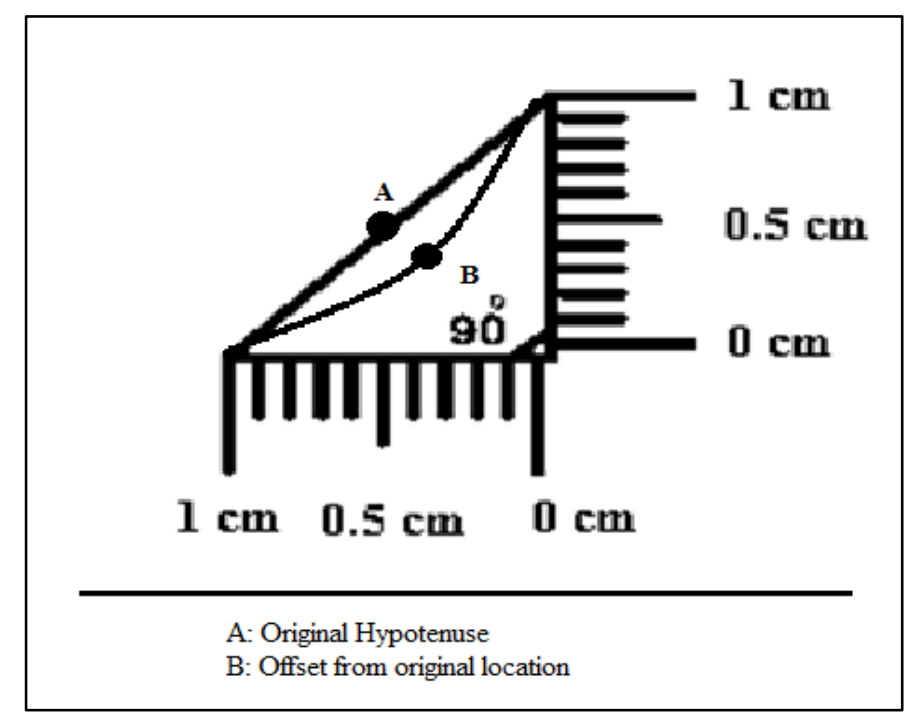

Figure (8)Curvature of the Hypotenuse

Equation one to calculate any disk (circle) radius if the radius length greater or equal to one centimeter.

$$
\text { Raduis length of any Disk }=\frac{\text { Ideal length of } P Q(1)}{\text { New length scale of } P Q(n)}
$$

When $\mathrm{AB}=\mathrm{BD}=1 \mathrm{~cm}$, Ideal $\mathrm{PQ}$ (At one centimeter radius) length is a Kisaa value (constant) which is PQ (1), PQ $=0.29289321881345247559915563789515 \mathrm{~cm}$. PQ (n) is the PQ length of any unknown disk radius length, If $0<\mathrm{PQ}(\mathrm{n}) \leq \mathrm{PQ}(1), \mathrm{n}>1$.

\section{CASE B DERIVATION}

If the Disk (circle) has radius length less than one centimeter, and by following the same steps in case A derivation, see figure (9), AB \& BD \& DP \& AP $=0.5 \mathrm{~cm}, \mathrm{P}$ are the center points of the circle (disk), Pythagorean steps to find PC. $\mathrm{PC}=0.35355339059327376220042218105242, \mathrm{PQ}=0.5$ $\mathrm{cm}$ PQ is the radius of the circle but PQ (n) = 0.14644660940672623779957781894758 . 
Web Site: https://jutq.utq.edu.iq/index.php/main Email: journal@jutq.utq.edu.iq

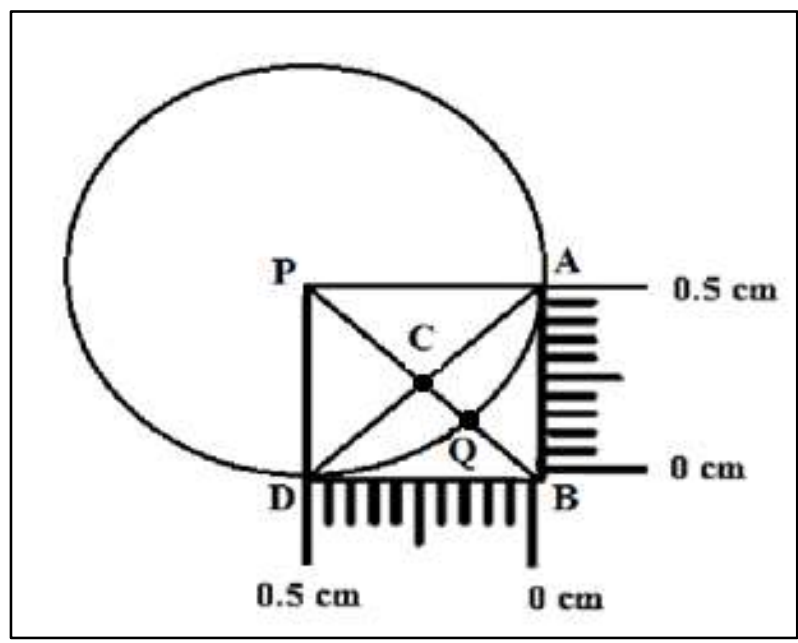

Figure (9) Radius Equal to half Centimeter

If the circle has radius $0.99 \mathrm{~cm}$ this mean the $\mathrm{PQ}(\mathrm{n})=$ 0.2899642866253179508431640815162 , if the radius 0.34 this mean the PQ $(\mathrm{n})=0.09958369439657384170371291688435$, if the radius $=0.25$ this means:PQ $(\mathrm{n})=0.07322330470336311889978890947379$. Table (3).

Table (3) Experimental of Decreasing PQ length

\begin{tabular}{|c|c|c|}
\hline No. & Disk Radius & PQ length PQ (n) \\
\hline 1 & $1 \mathrm{~cm}$ & $0.29289321881345247559915563789515 \mathrm{~cm}$ \\
\hline 2 & $0.99 \mathrm{~cm}$ & $0.2899642866253179508431640815162 \mathrm{~cm}$ \\
\hline 3 & $0.5 \mathrm{~cm}$ & $0.14644660940672623779957781894758 \mathrm{~cm}$ \\
\hline 4 & $0.34 \mathrm{~cm}$ & $0.09958369439657384170371291688435 \mathrm{~cm}$ \\
\hline 5 & $0.25 \mathrm{~cm}$ & $0.07322330470336311889978890947379 \mathrm{~cm}$ \\
\hline Etc. & Etc. & Etc. \\
\hline
\end{tabular}




\section{CASE B CONCLUSION}

From Table (3) we can conclude there is a constant decreasing of PQ length, this decreasing or (multiplying) is constant Coefficient equally at each order to the radius decreasing, Multiplying means there is not ambiguity if the two right angle side be static and remain one centimeter length, Nevertheless the disk can change and have any radius length (Decreasing less than or equal to one centimeter length), see table (4) Applying dividing operation on PQ length values. Fortunately there is a clear constant can be deduce and it can be used to calculate the radius length. Decreasing the length of the disk means the PQ value length will be decreasing in the directly case with table (3) (Directly proportion. This derivation leads us to create a basic formula to calculate any unknowing radius for any disk only by using the right triangle (one by one centimeter) with a dynamic hypotenuse to compute the hypotenuse (curving) offset from the original site at one centimeter radius length, Curvature of the hypotenuse toward the right angle, see figure (8).

Table (4)Ratio Decreasing

\begin{tabular}{|l|}
\hline$\frac{P Q(1)}{P Q(1)}=1$ \\
\hline$\frac{P Q(2)}{P Q(1)}=0.99$ \\
$\frac{P Q(3)}{P Q(1)}=0.5$ \\
$\frac{P Q(4)}{P Q(1)}=0.34$ \\
\hline$\frac{P Q(5)}{P Q(1)}=0.25$ \\
\hline
\end{tabular}


Web Site: https://jutq.utq.edu.iq/index.php/main Email: journal@jutq.utq.edu.iq

Equation two to calculate any disk (circle) radius if the radius length less than or equal to one centimeter.

$$
\text { Raduis length of any Disk }=\frac{\text { New length scale of } P Q(n)}{\text { Ideal length of } P Q(1)}
$$

When $\mathrm{AB}=\mathrm{BD}=1 \mathrm{~cm}$, Ideal PQ (At one centimeter radius) length is a Kisaa value (constant) which is PQ (1), PQ $=0.29289321881345247559915563789515 \mathrm{~cm} . \mathrm{PQ}(\mathrm{n})$ is the PQ length of any unknown disk radius length, If $0<\mathrm{PQ}(\mathrm{n}) \leq \mathrm{PQ}(1), \mathrm{n}>1$.

\section{FUTURE WORK}

Author suggests these two new equations with the Kisaa Constant to assist Industrial technologies and increase the precision in the calculations of engineering and mathematics through building and programming devices to calculate area and other belongings. These equations also help scientists in several fields such as space science and to calculate the diameters of celestial bodies for giving more accurate predictions of the vacuum and expansion of the universe. For other how interest in physical sciences, chemical, electronics, because these equations help to improve the functioning of electronic filters which enhance measurements of the wavelength more accura 
University of Thi-Qar Journal Vol.11 No.3 SEP 2016

Web Site: https://jutq.utq.edu.iq/index.php/main Email: journal@jutq.utq.edu.iq

REFERENCES

[1] Banchoff, T., 1994. On the Geometry of Piecewise Circular Curves. Mathematical Associatin of America, Volume 101, pp. 403-416.

[2] Beckmann, P., 1976. A History of Pi. s.l.: St. Martin's Griffin.

[3] Culbert, G., n.d. Circle Geometry and Three - dimensional subregular translation planes, s.1.: Universitiet Gent.

[4] D.P.Robbins, 1994. Areas of Polygon Inscribed in a Circle. Discrete Comput Geometry.

[5] Glass, H. J., 2013. Intersection area of stationary circle and a circle under a coupled axial rotation and translation. Journal of Geometry.

[6] Lange, S., 1985. The length of the circle. s.l.: Springer-Verlag.

[7] L, T., 2003. A Manual of Greek Mathematics. s.l.: Courier Dover Publications.

[8] Palani, V., 2010. Interesting Proofs for The circumference and Area of a Circle. The General science Journal.

[9] Thijsse, J. M., 2006. Computational Physics. s.l.:Cambridge University Press. 